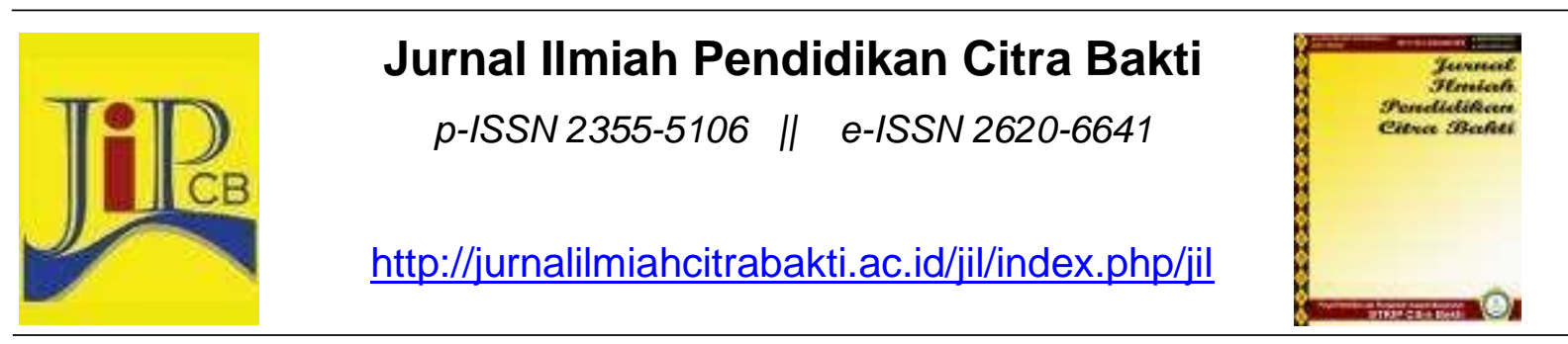

\title{
PENGARUH PELATIHAN JUMP ROPE TERHADAP DAYA LEDAK OTOT TUNGKAI PADA PERENANG USIA DINI
}

\author{
Komang Ayu Krisna Dewi \\ 1)Program Studi Pendidikan Olahraga, Universitas Pendidikan Ganesha \\ ${ }^{1)}$ komangayukrisnadewi123@gmail.com
}

\section{Histori artikel}

Received:

30 Agustus 2021

Accepted:

5 November 2021

Published:

18 November 2021

\begin{abstract}
Abstrak
Penelitian ini bertujuan untuk mengetahui pengaruh pelatihan jump rope dan terhadap daya ledak otot tungkai pada perenang usia dini. Penelitian ini menggunakan metode penelitian quasiexperimental dengan pendekatan one group pretest post-test design, yang dilakukan kepada 16 orang perenang kelompok usia IV (<10 tahun) Jalak Bali Swimming Club. Daya ledak otot tungkai perenang usia muda diukur menggunakan vertical jump dan waktu tempuh renang yang berfokus pada gerakan kaki yang dibantu oleh swimming kick board dalam jarak 25 meter. Hasil pengukuran selanjutnya dilakukan analisis, paired sample t-test untuk mengetahui pengaruh pelatihan jump rope. Hasil analisis menunjukkan bahwa pelatihan jump rope berpengaruh signifikan terhadap daya ledak otot tungkai pada perenang usia dini, baik pengukuran di darat maupun di air (sig. = $0.000<0.05, \mathrm{HO}$ ditolak). Sehingga, dapat disimpulkan penelitian ini adalah pelatihan jump rope dapat digunakan sebagai latihan rutin yang dilakukan oleh perenang usia dini di klub renang untuk meningkatkan daya ledak otot tungkai. Daya ledak otot tungkai yang maksimal akan dapat meningkatkan prestasi perenang usia dini dalam berkompetisi.
\end{abstract}

Kata-kata Kunci: jump rope, butt kick, daya ledak otot tungkai, perenang usia dini 


\begin{abstract}
Abstrak. This study aims to determine the effect of jump rope training and the explosive power of leg muscles in early age swimmers. This study used a quasi-experimental research method with a one group pretest post-test design approach, which was conducted on 16 swimmers in the age group IV (<10 years) Jalak Bali Swimming Club. The the explosive power of leg muscles of young swimmers was measured using a vertical jump and swimming travel time which focused on leg movements assisted by a swimming kick board within a distance of 25 meters. The measurement results were then analyzed using paired sample t-test to determine the effect of jump rope training. The results of the analysis showed that jump rope training had a significant effect on leg muscle explosive power in early age swimmers, both on dry land and water (sig. $=0.000<0.05, \mathrm{HO}$ rejected). So, it can be concluded from this research that jump rope training can be used as a routine exercise carried out by early age swimmers in swimming clubs to increase leg muscle explosive power. Maximum leg muscle explosive power will be able to improve the performance of early age swimmers in competition
\end{abstract}

Keywords: jump ropes training, leg muscle explosiveness, early age swimmers..

\title{
Latar Belakang
}

Renang gaya bebas (crawl atau freestyle stroke) merupakan salah satu gaya renang yang banyak dikuasai oleh masyarakat. Gaya renang ini dilakukan dengan sikap badan yang telungkup dan kedua kaki digerakkan secara linier atau seluruh anggota badan berada dalam satu garis lurus, yang dilakukan dengan menggerakkan kedua lengan selama berada di permukaan air (Rohman, 2019). Gaya bebas dianggap sebagai gaya renang tercepat dibandingkan dengan gaya berenang yang lainnya dan digunakan sebagai tolak ukur kemampuan berenang seseorang. Gaya renang ini diasumsikan sebagai gaya renang paling dasar yang harus dikuasai oleh perenang pemula sampai atlet renang profesional (Thomas, 2005). Capaian seseorang dalam menguasai renang gaya bebas tersebut diraih dengan melakukan latihan yang benar dan teratur, baik teknik dan kondisi fisik.

Pelatihan dalam meningkatkan kemampuan berenang memerlukan waktu panjang, dan harus dilakukan secara kontinu dan terpadu untuk mencapai kemampuan yang maksimal (Lekso, 2013). Saat ini, pelatihan renang tidak hanya dilakukan di dalam air, juga dilakukan latihan di darat, dengan tujuan untuk meningkatkan kekuatan otot dan kelenturan otot (Mardiani dkk., 2019: 206). Pada indikator daya ledak otot, pelatihan yang diberikan tidak hanya faktor peningkatan beban, akan tetapi harus memperhatikan faktor kecepatan konstraksinya. Daya ledak otot menjadi komponen penting yang dibutuhkan dalam olahraga. Dalam olahraga renang, daya ledak mempunyai pengaruh besar pada gerakan lengan dan gerakan kaki.

Hasil observasi yang dilakukan oleh peneliti di Kolam Renang Tirta Krisna Kabupaten Jembrana terhadap salah satu klub renang yang rutin melakukan latihan di Kolam Renang Tirta Krisna, Jalak Bali Swimming Club, didapatkan bahwa banyak perenang kelompok usia IV (berusia kurang dari 10 tahun) telah menguasai teknik renang gaya bebas yang meliputi 
gerakan kaki, gerakan tangan, dan cara mengambil napas. Hasil wawancara tidak terstruktur kepada Ketua Jalak Bali Swimming Club, I Gusti Komang Astawa, S.Pd, yang menyatakan bahwa perenang usia dini merupakan peserta didik tingkat sekolah dasar yang sebelumnya telah menerima pembelajaran renang dari sekolah ataupun telah mengikuti klub renang di wilayah Jembrana. Ketua klub tersebut juga menyebutkan bahwa latihan diberikan rutin kepada perenang dengan tujuan untuk memenuhi keterampilan dasar dan teknik/gaya berenang, salah satunya adalah gaya bebas. Berdasarkan temuan tersebut, peneliti memiliki ketertarikan terhadap kepelatihan renang pada perenang usia dini, ketertarikan peneliti berfokus pada peningkatan komponen fisik perenang usia dini dalam melakukan renang gaya bebas.

Hasil studi pendahuluan melalui observasi dan wawancara tidak terstruktur kepada pelatih di Jalak Bali Swimming Club, Kabupaten Jembrana didapatkan bahwa: 1) Perenang kelompok usia IV (berusia kurang dari 10 tahun) Jalak Bali Swimming Club telah dapat melakukan renang gaya bebas, dengan menguasai teknik dasar (seperti gerakan kaki, gerakan tangan, dan cara mengambil napas); 2) Perenang usia dini hanya melakukan pemanasan (streching) yang dilakukan di darat sebelum melakukan latihan di air; dan 3) Pemanasan yang telah dilakukan oleh perenang usia dini tidak diikuti dengan program latihan darat yang sistematis sebelum dilakukannya latihan di dalam air. Berdasarkan temuan tersebut, peneliti memiliki ketertarikan terhadap kepelatihan renang pada perenang usia dini, ketertarikan peneliti berfokus pada peningkatan komponen fisik perenang usia dini dalam melakukan renang gaya bebas, salah satunya dengan menerapkan pelatihan jump rope.

Jump rope atau lompat tali merupakan salah satu bentuk latihan kardio yang banyak dilakukan oleh atlet kelas dunia (Watson, 2017). Jump rope terdiri dari serangkaian gerakan melompati tali dengan menggunakan tumpuan satu atau dua kaki dan mendarat dengan dua kaki yang dilakukan secara berulang-ulang (Mutaqin, Hariyanto, \& Sudjana, 2017: 20). Manfaat jump rope diantaranya: 1) Mengembangkan daya tahan; 2) Mengembangkan kekuatan kaki dan lengan; 3) Mengembangkan kekuatan kardiovaskuler; 4) Membantu memahami ritme gerakan; 5) Membantu mengembangkan koordinasi tangan dan kaki; dan 6) Mengembangkan keseimbangan tubuh yang baik (Faqur, 2009: 23). Pelaksanaan jump rope sangat mudah dilakukan, yaitu dengan menggunakan seutas tali skipping dan tempat melompat yang datar. Latihan ini dapat dilakukan dimana saja dan kapan saja dan memiliki risiko cedera yang minimal.

Peneliti menyadari bahwa terbatasnya bukti hasil penelitian yang berkaitan dengan dampak latihan jump rope terhadap daya ledak otot tungkai perenang usia dini dalam melakukan berenang gaya bebas. Penelitian Ningsih dan Widodo (2019) mendapatkan 
bahwa terdapat pengaruh signifikan latihan jump rope terhadap peningkatan daya ledak otot tungkai mahasiswa putra usia 18-21 tahun. Berdasarkan hal tersebut, peneliti tertarik untuk melakukan penelitian terkait pengaruh pelatihan jump rope terhadap daya ledak otot tungkai pada perenang usia dini. Tujuan penelitian ini adalah mengetahui pengaruh pelatihan jump rope terhadap daya ledak otot tungkai pada perenang usia dini, baik pengukuran di darat maupun di air.

\section{Metode}

Jenis penelitian ini adalah penelitian quasi-experimental, dengan pendekatan one group pretest post-test design. Penelitian ini dilakukan kepada 16 orang perenang kelompok usia IV (berusia kurang dari 10 tahun) di Kolam Renang Taman Tirta Krisna, Kab. Jembrana. Sampel penelitian dipilih menggunakan teknik probability sampling dengan pendekatan simple random sampling. Kriteria inklusi yang ditetapkan diantaranya: 1) Perenang usia kelompok IV yang berusia 7-10 tahun; 2) Mempunyai Body Mass Index (BMI) ideal (18,524,9); dan 3) Mampu berenang dengan gaya bebas pada jarak 25 meter. Kriteria eksklusi yang digunakan dalam penelitian ini, diantaranya: 1) Calon sampel dengan penyakit fisik yang dapat menghambat proses penelitian; 2) Sampel yang mengalami cedera saat proses penelitian.

Data dalam penelitian ini didapatkan dengan melakukan pengukuran daya ledak otot di darat dengan menggunakan vertical jump dengan validitas 0,78 dan reliabilitas 0,93 (Jhonson \& Nelson, 1986: 124), dan di dalam air menggunakan waktu tempuh perenang dalam menggunakan gerakan kaki gaya bebas berbantuan swimming kick board dalam jarak 25 meter (satuan detik), dengan nilai reliabilitas sebesar 0,69 dan nilai validitas sebesar 0,95 (Kirkendall, Grubber, \& Joseph, 1980). Hasil pengukuran selanjutnya dilakukan sebelum dan sesudah diberikan pelatihan jump rope, sehingga peneliti dapat mengetahui pengaruh pelatihan terhadap subjek penelitian. Peneliti melakukan studi pendahuluan pada Klub "Jalak Bali Swimming Club" dan pada Kolam Renang Taman Tirta Krisna yang terletak di Jalan Merak, Calon sampel Jembrana, Kab. Jembrana. Studi pendahuluan bertujuan untuk mengetahui jumlah populasi, menyampaikan maksud penelitian yang dilakukan, dan mensurvei lokai penelitian sebelum proses pengambilan data. Pada tahap ini, peneliti memancang program pelatihan dan sarana pelatihan, yang meliputi rencana pelaksanaan pelatihan, absensi, tali skipping untuk jump rope, stopwatch, pengaris 1 meter, swimming kick board, peluit, dan kolam renang. Peneliti juga mempersiapkan lembar tabel tabulasi untuk mencatat hasil pretest dan post-test daya ledak tungkai.

Peneliti memilih dan mengumpulkan calon subjek penelitian sesuai dengan teknik sampling yang ditetapkan. Selanjutnya, peneliti menjelaskan proses penelitian, kontrak 
waktu latihan, dan meminta persetujuan menjadi partisipan penelitian (informed consent) dengan meminta tanda tangan dari subjek langsung yang disaksikan oleh orang tua atau wali. Program pelatihan disusun berdasarkan prinsip pelatihan dari Tudor O. Bompa dan G. Gregory Haff (2009). Pelatihan dilakukan selama 4 minggu yang dijadwalkan 3 kali pertemuan setiap minggunya. Latihan dilakukan setidaknya selama \pm 5-10 menit dengan rasio butt kick : istirahat sebesar 1:5 detik dengan jumlah repetisi 6 kali dan jumlah set 5-7 set setiap latihan, dengan fokus pada pergantian kaki cepat. Latihan yang dilakukan menerapkan intensitas latihan $70-80 \%$ Tabel program pelatihan dapat dilihat pada Tabel 1.

Hipotesis yang diuji pada penelitian ini adalah pelatihan jump rope memiliki pengaruh signifikan terhadap daya ledak otot tungkai pada perenang usia dini. Sebelum melakukan uji hipotesis, peneliti melakukan uji asumsi normalitas Shapiro Wilk. Hasil uji normalitas didapatkan menunjukkan bahwa nilai sig. > 0.05 (nilai pretest dan post-test, sehingga $\mathrm{H} 0$ ditolak dan bermakna bahwa data berdistribusi normal. Analisis dekriptif statistik digunakan untuk menyajikan data-data karakteristik demografi, yaitu: usia, jenis kelamin, dan lama belajar berenang gaya bebas. Analisis univariat digunakan untuk menganalisis variabel daya ledak otot tungkai. Pada penelitian ini menggunakan dua jenis pengujian komparatif parametrik (skala data interval) dengan membandingkan skor pretest dan post-test, sehingga uji yang dilakukan adalah paired sample t-test, dengan tingkat kepercayaan sebesar $95 \%$.

\section{Hasil dan Pembahasan}

Karakteristik Sampel Penelitian

Hasil penelitian menunjukkan perenang usia dini memiliki rata-rata usia 8.50 tahun (8.63 \pm 1.095$)$ dengan sebagian besar berusia 8 tahun (37.5\%). Pada karakteristik jenis kelamin menunjukkan bahwa sebagian besar perenang usia dini berjenis kelamin laki-laki, secara keseluruhan berjumlah 10 orang (62.5\%). Sedangkan pada karakteristik lama belajar, mayoritas perenang usia dini mayoritas telah belajar berenang gaya besar lebih dari 1 tahun, sebanyak 10 orang (62.5\%).

Analisis Univariat

Hasil analisis terkait daya ledak otot perenang usia dini pada pengukuran di darat dan di air (Tabel 3). Hasil pengukuran di darat menunjukkan pengukuran pretest mempunyai rata-rata $65.50 \mathrm{~cm}(65.50 \pm 30.535)$ dan post-test mempunyai rata-rata $74.75 \mathrm{~cm}(74.75 \pm$ 27.748). Sedangkan pada pengukuran di air menunjukkan pengukuran pretest mempunyai rata-rata $43.50 \mathrm{dtk}(43.50 \pm 5.422)$ dan post-test mempunyai rata-rata $38.56 \mathrm{dtk}$ (38.56 \pm 4.718).

Hasil analisis bivariat dengan paired sample t-test (Tabel 4), didapatkan bahwa perbedaan rata-rata pada pengukuran di darat sebesar $9.25(-9.25 \pm 3.661)$, sehingga dapat 
disimpulkan terjadi peningkatan pengukuran vertical jump sebesar $9.25 \mathrm{~cm}$ dari hasil pretest ke post-test. Selanjutnya didapatkan nilai sig. sebesar 0.000 , sehingga HO ditolak (nilai sig. < 0.05). Sedangkan pada pengukuran di air menggunakan kecepatan gerakan kaki gaya bebas yang dibantu dengan swimming kick board sejauh 25 meter, didapatkan perbedaaan rata-rata waktu tempuh sebesar $4.50(4.50 \pm 2.000)$, sehingga terjadi penurunan waktu sebesar 4.50 detik dari hasil pretest ke post-test. Selanjutnya didapatkan nilai sig. sebesar 0.000 , sehingga $\mathrm{HO}$ ditolak (nilai sig. < 0.05 ). Hasil pengujian tersebut dapat disimpulkan bahwa pelatihan jump rope memiliki berpengaruh signifikan terhadap daya ledak otot tungkai pada perenang usia dini di Kabupaten Jembrana, baik pengukuran di darat dan di dalam air.

Hasil analisis didapatkan bahwa pelatihan jump rope memiliki berpengaruh signifikan terhadap daya ledak otot tungkai pada perenang usia dini di Kabupaten Jembrana, baik pengukuran di darat dan di dalam air. Penelitian yang dilakukan oleh Ningsih dan Widodo (2019) mendapatkan bahwa latihan jump rope meningkatkan daya ledak otot tungkai mahasiswa putra usia 18-21 tahun. Penelitian lainnya yang mendukung yaitu penelitian yang dilakukan oleh Yani (2020) mendapatkan bahwa latihan jump rope selama 5 minggu dapat meningkatkan kekuatan otot tungkai peserta didik tingkat sekolah dasar. Menurut Benjamin (2020) latihan jump rope merupakan latihan yang baik untuk perenang yang bermanfaat untuk meningkatkan performa renang, memiliki dampak buruk yang rendah, dan dapat dilakukan hampir di mana saja. Disarankan untuk melakukan jump rope secara teratur selama 3 kali setiap minggu dengan durasi 30 menit setiap latihan, hal ini dapat meningkatkan efektifitas hasil berenang.

Peningkatan daya ledak otot setelah mengikuti pelatihan jump-rope dipengaruhi oleh peningkatan kekuatan otot. Kekuatan otot yang meningkat juga meningkatkan daya ledak otot, hal ini dapat dijelaskan bahwa daya ledak terdiri dari unsur kekuatan otot dan unsur kecepatan (Irawadi, 2011: 96). Kekuatan otot adalah kekuatan atau tegangan sebuah otot atau lebih yang bekerja melawan suatu tahanan dengan usaha maksimal. Kekuatan otot adalah kemampuan sekelompok otot yang melakukan kontraksi maksimal melawan beban (Widiastuti, 2011: 150). Peningkatan kekuatan otot tungkai ini disebabkan karena tubuh telah mengalami adaptasi terhadap olahraga yang diberikan. Sebagai akibat dari bertambahnya myofibril pada setiap serabut otot, meningkatnya densitas (kepadatan) kapiler pada setiap serabut otot, meningkatnya jumlah protein, dan bertambah jumlah serabut otot. Peningkatan kekuatan otot ini terjadi akibat adanya hipertropi (pembesaran) otot. Jika otot terlatih maka kekuatan otot pun dapat meningkat. 


\section{Kesimpulan}

Berdasarkan hasil analisis data dapat disimpulkan bahwa pelatihan jump rope berpengaruh signifikan terhadap daya ledak otot tungkai pada perenang usia dini. Berdasarkan kesimpulan di atas, peneliti memberikan saran sebagai berikut:

1. Perenang usia dini dapat melakukan latihan jump rope, jump rope adalah salah satu pilihan latihan yang mudah dilakukan untuk meningkatkan daya ledak otot tungkai.

2. Pelatih Jalak Bali Swimming Club, dapat menerapkan latihan jump rope sebagai latihan rutin perenang yang bergabung di klub renang, dalam meningkatkan daya ledak otot tungkai yang bermanfaat dalam performa renang gaya bebas.

3. Peneliti selanjutnya disarankan untuk melakukan penelitian yang lebih luas mengenai pengaruh latihan jump rope terhadap daya ledak otot pada perenang di berbagai jenjang usia dan membandingkannya dengan jenis pelatihan yang lain, sehingga terdapat keterbaruan pengetahuan di bidang kepelatihan renang.

\section{Daftar Pustaka}

Benjamin. (2020). Jump Rope For Swimmers: 9 Reasons Every Swimmer Should Do It. Retrieved December 22, 2020, from https://swimcompetitive.com/drylandtraining/jump-rope-for-swimmers/

Bompa, T. O., \& Haff, G. G. (2009). Periodization: Theory and Methodology of Training. USA: Human Kinetics.

Domitilla, F., \& Yani, S. (2020). Pengaruh Jump Rope Training Terhadap Kekuatan Otot Tungkai pada Siswa Sekolah Dasar. Journal IImiah Kesehatan Masyarakat, 12(2), 84-88.

Faqur, M. M. (2009). Permainan pengembangan kecerdasan kinestika anak dengan media tali. Jakarta: PT. Gramedia Widiasarana Indonesia.

Irawadi, H. (2011). Kondisi fisik dan pengukuran. Padang: UNP Press.

Jhonson, L. B., \& Nelson, K. J. (1986). Practical Measuremenrt for Evaluation in Physical Education (4th ed.). New York: illan Publishing Company.

Kirkendall, Grubber, D. R., \& Joseph, J. (1980). Measurement and Evaluation for Physical Educator. USA: Brown Company Publisher.

Lekso, M. F. (2013). Pengaruh Metode Latihan Dan Power Tungkai Terhadap Kecepatan Renang Gaya Dada 50 Meter Atlet Kelompok Umur IV Perkumpulan Renang Spectrum Semarang. Journal of Physical Education and Sports, 2(1), 212-219. Retrieved from https://journal.unnes.ac.id/sju/index.php/jpes/article/view/1275

Mardiani, U., Sugiyanto, \& Furqon, M. (2019). Pengaruh Kombinasi LatihanTeknik Renang Gaya Bebas Menggunakan Alat dan Latihan Fisik Tanpa Alat Terhadap Kecepatan Renang 25 Meter Gaya Bebas (Crawl). The 9th University Research Colloqium 2019, 9(2), 205-210.

Mutaqin, R. T., Hariyanto, E., \& Sudjana, I. N. (2017). Pengaruh Latihan Skipping dan Side 
Hop Terhadap Keterampilan Dribbling Pada Anak Didik U16-17 SSB PSDM Kabupaten Blitar. Gelanggang Pendidikan Jasmani Indonesia, 1(1), 14.

Ningsih, J. R., \& Widodo, A. (2019). Pengaruh Latihan Rope Jump Terhadap Peningkatan Daya Ledak Otot Tungkai Mahasiswa Putra Usia 18-21 Tahun. Jurnal Kesehatan Olahraga, 7(2), 391-398.

Rohman, U. (2019). Penerapan Metode Latihan Interval Dalam Meningkatkan Kecepatan Renang Gaya Bebas 50 Meter. Jurnal IImiah SPIRIT, 19(1). Retrieved from http://ejournal.utp.ac.id/index.php/JIS/article/view/959

Thomas, D. (2005). Swimming: Steps to success (3rd ed.). United States: Human Kinetics.

Watson, K. (2017). Balanced workout routine with jump rope can help you lose weight. Retrieved January 3, 2020, from https://www.healthline.com/health/jumping-rope-tolose-weight

Widiastuti. (2011). Tes dan Pengukuran Olahraga. Jakarta: PT Bumi Timur Jaya. 